University of Nebraska - Lincoln

DigitalCommons@University of Nebraska - Lincoln

Faculty Publications: Agricultural Leadership, Education \& Communication Department
Agricultural Leadership, Education \& Communication Department

April 1992

\title{
Analysis of Laboratory Management Competencies in Nebraska Agricultural Education Programs
}

\author{
Neal J. Schlautman \\ lowa State University \\ Thomas A. Silletto \\ University of Nebraska - Lincoln
}

Follow this and additional works at: https://digitalcommons.unl.edu/aglecfacpub

Part of the Other Public Affairs, Public Policy and Public Administration Commons

Schlautman, Neal J. and Silletto, Thomas A., "Analysis of Laboratory Management Competencies in Nebraska Agricultural Education Programs" (1992). Faculty Publications: Agricultural Leadership, Education \& Communication Department. 22.

https://digitalcommons.unl.edu/aglecfacpub/22

This Article is brought to you for free and open access by the Agricultural Leadership, Education \& Communication Department at DigitalCommons@University of Nebraska - Lincoln. It has been accepted for inclusion in Faculty Publications: Agricultural Leadership, Education \& Communication Department by an authorized administrator of DigitalCommons@University of Nebraska - Lincoln. 


\title{
Analysis of Laboratory Management Competencies in Nebraska Agricultural Education Programs
}

\author{
Neal J. Schlautman, Instructor \\ Iowa State University \\ Thomas A. Silletto, Professor \\ University of Nebraska
}

Laboratory learning has long been associated with the educational process. The use of school and community laboratories in which students "learn by doing" is an integral part of agricultural education programs (Sutphin, 1984).

Effective scheduling and management of the agricultural mechanics laboratory is a must for carrying out an effective instructional program (Shinn, 1987; Bear \& Hoemer, 1986). The ability to manage laboratory learning was rated as a highly important ability for agriculture teachers by first-year agriculture teachers (Barrick and Powell, 1986). Agriculture instructors must be prepared so they possess and practice laboratory management competencies in order to maximize the opportunity for student learning (Henderson, 1983). Johnson and Schumacher (1989) defied laboratory management competencies as those abilities needed by secondary agriculture teachers to direct, conduct, or administer an agricultural mechanics laboratory.

Hoerner and Bekkum (1990) reported that agriculture instructors in seven selected states taught an average of two agricultural mechanics classes per semester. Schlautman and Foster (1991) indicated that secondary agricultural education teachers in Nebraska devoted 29.6 percent of their time to agricultural mechanics instruction. Many agriculture courses allot one-third to two-thirds of the total instructional time to individual and group laboratory activities (Shinn, 1987). The large percentage of instructional time spent in laboratory settings suggests the need for sound laboratory management practices.

Johnson et. al. (1990) found that Missouri secondary agriculture teachers have inservice needs in the area of agricultural mechanics laboratory management. The greatest inservice needs were in the area of safety. Johnson et. al. suggested research be conducted to identify a core of common laboratory management competencies essential to all phases of laboratory instruction.

Johnson and Schumacher (1989) surveyed post-secondary, college and university agricultural mechanics experts to identify and prioritize a list of 50 laboratory management competencies which the experts perceived as important in order to effectively manage a secondary school agriculture mechanics laboratory. The authors concluded that teacher educators should provide present and prospective agriculture teachers experiences designed to develop and enhance these skills. They also stated that further research should be conducted to determine the extent to which agriculture teachers possess and practice these laboratory management competencies. This study was conducted in response to their call for further research.

\section{Purpose and Objectives}

The purpose of this study was to determine the degree of laboratory management competence possessed and practiced by Nebraska secondary agricultural education instructors. Specific objectives were to determine:

The degree of competence possessed and degree of competence practiced by secondary agricultural education instructors for 50 specified laboratory 
If significant differences exist between the mean levels of competence possessed and competence practiced for each of the 50 specified laboratory management competencies.

Content areas that may need strengthening in the undergraduate agricultural education course in laboratory management at the University of Nebraska-Lincoln (UNL).

Laboratory management inservice needs of current secondary agricultural education instructors.

\section{Methods and Procedure}

The population for this study consisted of 128 secondary agricultural education instructors in Nebraska who were actively teaching during the 1990-91 school year, as identified by the Nebraska State Department of Education. A simple random sample of 40 secondary agricultural education instructors was drawn using a random numbers chart. Cohen's (1977) power analysis was used to determine the appropriate sample size. Useable responses were received from 35 of the 40 teachers for an 88 percent response rate.

A mailed questionnaire was used to collect the data. The list of agricultural mechanics laboratory management competencies used in this research was obtained from a study by Johnson and Schumacher (1989) in which a group of experts identified 50 competencies essential for effective laboratory instruction. A panel of experts from both Iowa State University and the University of Nebraska-Lincoln reviewed the questionnaire before actual use. The instrument had an overall reliability (Cronbach alpha) coefficient of .98 .

Respondents were asked to rate their degree of competence possessed and their degree of competence practiced for each of the 50 specified laboratory management competencies. A Likert-type scale of 1 to 5 was used with a response of 1 indicating a low degree of competence possessed or practiced and a response of 5 indicating a high degree of competence possessed or practiced. Selected demographic information was also collected.

The data were analyzed using SPSSx. Frequencies, percentages and means were calculated for the selected demographic characteristics of the respondents. Means and standard deviations were computed for the degree of competence possessed and degree of competence practiced. A T-test was used to determine if significant differences existed between the mean levels of competence possessed and mean level of competence practiced for each of the fifty management competencies. A mean rating below 3.00 for the degree of competence possessed or practiced was used to identify items for strengthening in the undergraduate laboratory management course and to identify items for inclusion in an inservice course for current secondary agricultural educators.

\section{Findings}

The average age of the respondents was 35.0 years with an average of 12.0 years of high school agriculture teaching experience. The respondents indicated the average enrollment in their high school agriculture classes was 47.5 students and that 27.5 percent of their program was dedicated to teaching agricultural mechanics. The average number of undergraduate college credit hours in mechanized agriculture courses was 13.0. 
The mean ratings for degree of competence possessed and degree of competence practiced are detailed in Table 1 along with the standard deviation for each. The fifty laboratory management competencies are listed in descending order by degree of competencie possessed. Also listed, for comparison purposes, is how the experts in Johnson and Schumacher's research ranked each of the fifty competencies (some items received the same mean score and thus the same ranking).

The mean ratings for degree of competence possessed exceeded 3.00 for all of the fifty items, indicating that Nebraska agriculture teachers possess above average competence for each of these items. Fifteen of the laboratory management competencies received a mean score of 4.00 or above, indicating a high degree of competence possessed for those 15 items. The item with the highest rating for degree of competence possessed was "operate within the limits of a budget." The standard deviation for this item was the lowest of all items rated, indicating the greatest amount of agreement among the respondents. The management competency receiving the lowest rating for degree of competence possessed was "computerize lab management functions." Two of the lowest rated ten items related to computerization procedures and the standard deviation of these two items was the largest of all items rated.

Two of the fifty competencies received a mean rating of 4.00 or above for the degree of competence practiced, thirty-eight of the competencies received a mean rating in the 3.00 to 3.99 range, and ten of the management competencies received a mean score of 2.99 or below for degree of competence practiced. The competency receiving the highest rating for degree of competence practiced was the same competency that received the highest rating for degree of competence possessed, "operate within the limits of a budget." The item receiving the lowest mean score for degree of competence practiced was "color code the laboratory." A graphical comparison of the number of items out of 50 that fell into respective mean rating categories for degree of competence possessed and degree of competence practiced is presented in Figure 1.

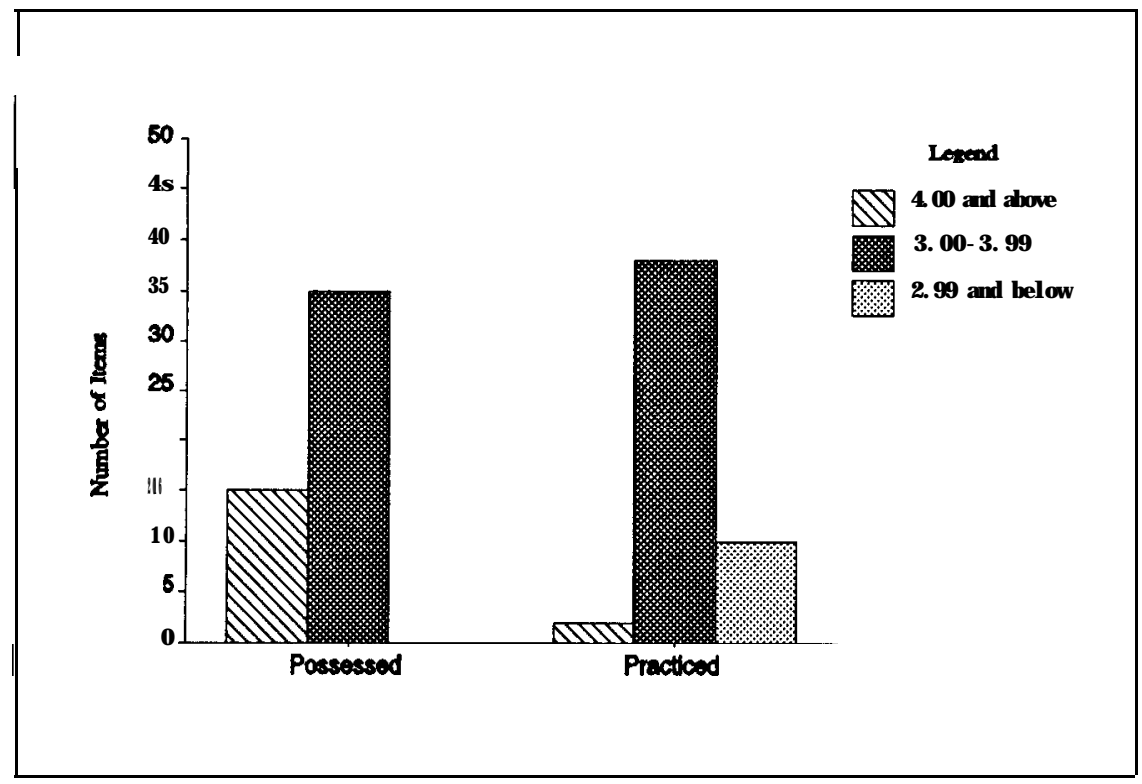

Figure 1. Number of items in respective mean rating categories for degree of competence possessed and degree of competence practiced. 
Table 1. Means and comparisons of competence possessed and practiced for fifty laboratory management competencies

\begin{tabular}{|c|c|c|c|c|c|}
\hline Management Competency & $\begin{array}{l}\text { Mean } \\
\text { Poss }\end{array}$ & S.D. & $\begin{array}{l}\text { Mean } \\
\text { Pract }\end{array}$ & S.D. & $\begin{array}{l}\text { Expert } \\
\text { Ranking }\end{array}$ \\
\hline Operate within the limits of a budget & 4.51 & 0.65 & 4.40 & 0.66 & 15 \\
\hline Develop lab cleanup procedures - & 4.31 & 0.83 & 3.60 & 1.04 & 8 \\
\hline Make minor equipment repairs & 4.26 & 0.89 & 4.31 & 0.80 & 25 \\
\hline Develop and enforce student discipline policy & 4.23 & 0.81 & 3.97 & 0.79 & 8 \\
\hline Provide and document safety instruction & 4.17 & 0.86 & 3.74 & 1.19 & 1 \\
\hline $\begin{array}{l}\text { Develop/maintain file of equipment operator } \\
\text { manuals }\end{array}$ & 4.14 & 0.94 & 3.71 & 1.23 & 22 \\
\hline $\begin{array}{l}\text { Arrange for professional assistance for } \\
\text { major repairs }\end{array}$ & 4.14 & 1.06 & 3.94 & 1.14 & 22 \\
\hline Make minor facility repairs & 4.11 & 0.87 & 3.97 & 0.82 & 50 \\
\hline Inventory tools and equipment & 4.11 & 1.05 & 3.66 & 1.03 & 25 \\
\hline $\begin{array}{l}\text { Identify equipment needed to teach mechanics } \\
\text { skills }\end{array}$ & 4.09 & 0.89 & 3.63 & 0.97 & 12 \\
\hline Maintain consumable supply inventory & 4.09 & 0.92 & 3.51 & 1.12 & 22 \\
\hline Perform routine maintenance & 4.06 & 0.84 & 3.83 & 0.86 & 29 \\
\hline Recognize quality tools and equipment & 4.06 & 1.03 & 3.89 & 0.96 & 25 \\
\hline Select, maintain protective equipment & 4.03 & 0.86 & 3.66 & 0.84 & 6 \\
\hline Store hazardous materials safely & 4.03 & 0.92 & 3.57 & 0.95 & 2 \\
\hline $\begin{array}{l}\text { Utilize technical manuals to order replace- } \\
\text { ment parts }\end{array}$ & 3.97 & 0.99 & 3.86 & 0.94 & 38 \\
\hline Update course offerings & 3.97 & 0.99 & 3.69 & 0.93 & 3 \\
\hline Construct welding booths, etc. & 3.97 & 1.01 & 3.54 & 1.12 & 45 \\
\hline Brand or mark tools to prevent theft & 3.97 & 1.10 & 3.49 & 1.07 & 34 \\
\hline Maintain healthy environmental conditions & 3.94 & 0.77 & 3.69 & 0.87 & 12 \\
\hline Safely arrange shop equipment & 3.89 & 0.80 & 3.57 & 0.85 & 4 \\
\hline Develop educational projects and activities & 3.89 & 0.83 & 3.54 & 0.89 & 30 \\
\hline Diagnose malfunctioning lab equipment & 3.89 & 0.93 & 3.66 & 1.03 & 18 \\
\hline Develop student billing procedures & 3.86 & 0.88 & 3.49 & 0.95 & 42 \\
\hline Document student competencies & 3.83 & 0.82 & 3.37 & 1.06 & 18 \\
\hline Develop lab policy & 3.83 & 1.05 & 3.69 & 0.92 & 20 \\
\hline Develop objective student evaluation criteria & 3.80 & 0.83 & 3.46 & 0.89 & 8 \\
\hline $\begin{array}{l}\text { Identify current references and technical } \\
\text { manuals }\end{array}$ & 3.77 & 0.91 & 3.43 & 0.85 & 14 \\
\hline Silhouette tool cabinets & 3.77 & 1.14 & 2.80 & 1.28 & 43 \\
\hline Store and distribute student supplies & 3.74 & 1.01 & 3.57 & 0.98 & 34 \\
\hline Conduct safety inspections & 3.74 & 1.04 & 3.31 & 0.93 & 5 \\
\hline Plan a public relations program & 3.74 & 1.04 & 3.29 & 1.05 & 41 \\
\hline Develop an accident reporting system & 3.74 & 1.04 & 3.29 & 1.15 & 15 \\
\hline Maintain, install safety devices & 3.69 & 1.08 & 3.51 & 0.98 & 7 \\
\hline Maintain file of educational projects & 3.69 & 1.11 & 3.40 & 0.98 & 37 \\
\hline Administer first aid & 3.57 & 1.20 & 3.40 & 1.06 & 31 \\
\hline Plan and implement student recruitment & 3.57 & 1.22 & 3.34 & 1.06 & 39 \\
\hline $\begin{array}{l}\text { Estimate time requirements for students } \\
\text { to complete their projects }\end{array}$ & 3.54 & 0.95 & 3.31 & 0.93 & 40 \\
\hline $\begin{array}{l}\text { Develop procedures to store, secure, and } \\
\text { check out tools and equipment }\end{array}$ & 3.46 & 1.15 & 3.00 & 1.03 & 32 \\
\hline Develop equipment maintenance schedule & 3.43 & 1.15 & 2.77 & 1.06 & 36 \\
\hline Computerize student records & 3.43 & 1.58 & 2.63 & 1.44 & 46 \\
\hline Develop a rotational shop plan & 3.40 & 1.01 & 2.77 & 1.00 & 28 \\
\hline Equip work stations for skill areas & 3.40 & 1.04 & 2.97 & 1.10 & 20 \\
\hline Comply with OSHA standards in the lab & 3.37 & 0.97 & 2.97 & 1.04 & 11 \\
\hline Install major equipment & 3.37 & 1.11 & 3.00 & 1.09 & 48 \\
\hline
\end{tabular}




\begin{tabular}{lllllc}
\hline & Mean & & Mean & \multicolumn{2}{c}{ Expert } \\
Management Competence & Poss & S.D. & Pract & S.D. & Ranking \\
\hline Color code laboratory & 3.26 & 1.09 & 2.34 & 1.21 & 15 \\
Prepare bid specifications & 3.26 & 1.25 & 3.11 & 1.16 & 33 \\
Make major equipment repairs & 3.17 & 1.20 & 2.66 & 1.03 & 49 \\
Modify the facility for handicapped students & 3.11 & 1.21 & 2.40 & 1.09 & 44 \\
Computerize lab management functions & 3.11 & 1.59 & 2.46 & 1.34 & 47 \\
\hline
\end{tabular}

aScale: 1 to $5.1=$ low degree, $3=$ average, $5=$ high degree of competence.

bJohnson and Schumacher (1989)

The results of the T-tests revealed a significant difference between the mean level of competence possessed and mean level of competence practiced at the .05 level for forty of the fifty competencies. The ten competencies that were not significantly different were operate within the limits of a budget, make minor equipment repairs, arrange for professional assistance for major repairs, make minor facility repairs, utilize technical manuals to order replacement parts, develop lab policy, maintain/install safety devices, administer first aid, plan and implement student recruitment and prepare bid specifications.

An apriori level below 3.00 for the respondents' mean rating of competence possessed or competence practiced was used to determine laboratory management areas that should be strengthened in the undergraduate laboratory management course for agricultural education majors at UNL and to determine which areas should be included in an inservice course for current agriculture instructors. This level was selected because it was felt that all fifty competencies, as identified by national experts, should be possessed and practiced above average. The results of this study indicated that all 50 management competencies were rated above this level (3.00) for degree of competence possessed. Ten items were identified as being practiced below average (below 3.00). The ten were silhouette tool cabinets, develop equipment maintenance schedule, computerize student records, equip work stations for skill areas, develop a rotational shop plan, comply with OSHA standards in the lab, color code the laboratory, make major equipment repairs, computerize lab management functions and modify the facility for the handicapped.

\section{Conclusions}

It was found that secondary Nebraska agricultural educators possess above average competence (mean rating greater than 3.00) for each of the fifty specified laboratory management competencies. The degree of competence practiced was above average for 38 of the competencies (mean rating of 4.00 or greater), average for 2 of the competencies (mean rating of 3.00 to 3.99) and below average for 10 of the competencies (mean rating less than 3.00). The ten competencies rated below average were targeted for strengthening in the undergraduate laboratory management class at UNL and for inclusion in an inservice course for current secondary agricultural educators.

The competency receiving the highest rating for degree of competence possessed and degree of competencie practiced was "operate within the limits of a budget." The competency receiving the lowest mean rating for degree of competence possessed was "computerize lab management functions" and the competency receiving the lowest rating for degree of competence practiced was "color code the laboratory." The standard deviations indicated the greatest agreement among the teachers for the item "operate within the limits of a budget" and the least agreement for the two items related to computerization procedures. A wide disparity exists among Nebraska agriculture teachers in the degree of computer competency possessed for laboratory management functions. 
Secondary agricultural educators in Nebraska do not practice laboratory management competencies to the degree possessed. Forty of the fifty items were rated significantly lower for degree of competence practiced versus degree of competence possessed. This indicates that while teachers possess above average competence for the fifty laboratory management competencies, they do not practice most of these $(80 \%)$ to the level possessed. Several of the ten items that were practiced to the degree possessed related to repair of equipment or purchasing equipment. Only two of the competencies related to safety were practiced to the degree possessed, those two being "maintain, install safety devices" and "administer first aid."

This research effort did not seek out the reasons why teachers do not practice laboratory management competencies to the degree possessed, but several reasons may be surmised, including time limitations, critical needs and budget restrictions. The teachers may only have enough time to practice a competency to a certain level, which may be well below the level they possess. For their situation, a specific laboratory management competency may not be critically needed. For instance, a rotational shop plan may not be needed for small class sizes or labs with sufficient equipment. Budget restrictions may preclude certain competencies, such as computerization or facility modification.

\section{Recommendations and Implications}

In order to ensure that all prospective secondary agricultural educators possess the competencies necessary to effectively manage an agricultural mechanics laboratory, it is recommended that the enrollment requirement be continued for the undergraduate laboratory management course at UNL. The undergraduate laboratory management course should continue to stress these fifty management competencies, and should be strengthened for the ten competencies identified.

This study indicates that current secondary agricultural educators possess laboratory management competencies. but they must practice these competencies in their own programs for them to be effective. It is recommended that an inservice course be conducted for current secondary educators. This inservice course should address the ten competencies being practiced below average, discuss reasons why management competencies are not practiced to the degree possessed, discuss on current laboratory use other than agricultural mechanics and address the laboratory management competencies needed to maintain those that current teachers do not possess.

The results of this research have several implications for teacher educators. Current and prospective secondary agriculture teachers must be properly trained to provide the best and most up-to-date instruction possible. Expansion of mechanization technology and laboratory practices beyond the realm of the traditional "shop" classes and into new laboratory areas such as aquaculture, horticulture, natural resources, and small animals provide exciting opportunities for students to learn via the hands-on approach. These new laboratory areas also give teachers an opportunity to educate students about the physical facilities and equipment involved with each of these laboratories. But expansion of the curriculum into these laboratory areas also calls for proper management procedures from the instructor in charge. Most Nebraska secondary agriculture teachers are familiar with the management competencies necessary to effectively operate an agricultural mechanics laboratory. Teacher educators must concentrate on converting this management knowledge to new laboratory settings, and conduct research to determine the different laboratory settings in use in Nebraska

\section{References}


Barrick, K. R. \& Powell, R. L. (1986). Assessing needs and planning inservice education for first year vocational agriculture teachers. Proceedings of the Thirteenth Annual National Agricultural Education Research Meeting. Dallas, Texas.

Bear, W. F. \& Hoemer, T. A. (1986). Plannina. organizing, and teaching agricultural mechanics. St. Paul, MN: Hobar Publications.

Cohen J. (1977). Statistical power analvsis for the behavioral sciences. New York: Academic Press.

Henderson, J. L. (1983). w-on-task behavior in selected vocational horticulture laboratories. Unpublished doctoral dissertation, Mississippi State University, Mississippi State.

Hoemer, T. A. \& Bekkum, V. A. (1990). Factors related to safety instruction in secondary agricultural mechanics programs in seven selected states. Paper presented to the Agricultural Mechanics Special Interest Group during the 44th Annual Central States Seminar in Agricultural Education/Agribusiness. Chicago, IL.

Johnson, D. M. \& Schumacher, L. G. (1989). Agricultural mechanics specialists identification and evaluation of agricultural mechanics laboratory management competencies: A modified Delphi approach. Journal of Aericultural Education. 30(3), 23-28.

Johnson, D. M., Schumacher, L. G. \& Stewart, B. R. (1990). An analysis of the agricultural mechanics laboratory management inservice needs of Missouri agriculture teachers. Journal of Aericultural Education. 31(2), 35-39.

Schlautman, N. J. \& Foster, R. M. (1991). The future of secondary agricultural mechanics instruction in Nebraska. The Journal of Agricultural Mechanization. $\underline{6}(2), 13-19$.

Shinn, G. (1987). September. The time to improve your laboratory teaching. The Aericultural Education Magazine. 60(3), 16-17.

Sutphin, H. D. (1984. SOE: Laboratories. The Agricultura/Education_Magazine. 56(10), 4. 